\title{
A study of magnesium supplementation on sensory nerve conduction velocity (N.C.V) in patients of diabetic neuropathy
}

\author{
Ashutosh Bhardwaj ${ }^{1}$, Pooja Chaurasia ${ }^{2, *}$, Arun Chaturvedi ${ }^{3}$ \\ ${ }^{1}$ Associate Professor, ${ }^{2}$ Junior Resident, ${ }^{\mathbf{3}}$ Associate Professor, Dept. of Physiology, Sarojani Naidu Medical College, Agra, Uttar \\ Pradesh, India
}

*Corresponding Author:

Email: poojachaurasia21.pc@gmail.com

Received: $5^{\text {th }}$ April, 2018

Accepted: $2^{\text {nd }}$ June, 2018

\begin{abstract}
Introduction: Globally, diabetes is the leading known cause of neuropathy. In type 2 diabetes mellitus, neuropathy being the most common complication contributes to majority of morbidity and mortality in such patients. Hyperglycemia is the main risk factor for diabetic neuropathy. A positive association exists between low serum magnesium levels and symptoms characteristics of peripheral neuropathy.

Materials and Methods: The study was done in 60 diabetic neuropathy patients attending the neurology O.P.D of S.N Medical College \& hospital, between February 2009 to August 2010. These patients were divided into two groups. Group I (n=30) receiving magnesium and metformin therapy for a period of 16 weeks. Group II $(n=30)$ receiving only metformin therapy. The blood samples were collected and analyzed for serum magnesium at $0,4,8,16$ weeks respectively. Nerve conduction velocity for common peroneal nerve was done at $0,4,8,16$ weeks respectively. Average of males in group 1 was $54.36 \pm 1.18 \mathrm{yrs}$ and of females was $53.09 \pm 1.47 \mathrm{yrs}$ and in group II was $55.94 \pm 1.62 \mathrm{yrs}$ and of females was $52.83 \pm 1.58 \mathrm{yrs}$ respectively.

Results: In Group I mean baseline value for sensory N.C.V of sural nerve is $42.23 \pm 0.76$ and after treatment values at 4 weeks is $46.85 \pm 0.99,8$ weeks $49.57 \pm 1.08$, at 16 weeks $50.62+0.85$ respectively. The difference between before and after treatment was extremely significant in Group I. In Group II Mean Baseline value for sensory N.C.V of Sural N. is $42.89 \pm 0.63$ and after treatment values at 4 weeks is $43.74+0.63,8$ weeks 44.1310 .61 , and at 16 weeks $44.53 \pm 0.62$ respectively. Statistically insignificant difference was observed in group II patients for sensory nerve conduction velocity before and after treatment values at 16 weeks $(\mathrm{p}>0.05)$.

Conclusion: Magnesium supplementation along with regular anti diabetic therapy improves sensory nerve conduction velocity.
\end{abstract}

Keywords: Diabetic neuropathy, Magnesium supplementation, Sensory nerve conduction velocity.

\section{Introduction}

Globally, diabetes is the leading known cause of neuropathy. In type $2 \mathrm{DM}$, neuropathy being the most common complication contributes to majority of morbidity and mortality in such patients. Hyperglycemia is the main risk factor for diabetic neuropathy.

Magnesium has a major role in carbohydrate metabolism. The release and activity of insulin is influenced by magnesium. Magnesium supplementation seems to benefit individuals with poorly controlled diabetes because hyperglycemia is associated with loss of magnesium in urine. It has been observed that low magnesium levels in serum is associated with decreased insulin secretion, impaired glucose tolerance and insulin resistance. ${ }^{1}$ Magnesium is necessary for insulin action and effectiveness of insulin. Magnesium deficiency is the most evident disturbance of metal metabolism in diabetes mellitus. Hypomagnesaemia which may present as acute metabolic or chronic complication in diabetes is the most evident disturbance of metal metabolism in diabetes mellitus. Magnesium is transported intracellular from blood under the influence of insulin.

Peripheral neuropathy is one of the most common complications in diabetes mellitus. Magnesium is important for normal nerve conduction, so its deficiency worsen the neuropathy in diabetes mellitus. ${ }^{2}$ Both insulin sensitivity and glycemic control can be improved by oral magnesium supplementation. In a study conducted previously, evidence suggestive of relation of insulin sensitivity and serum magnesium concentration was obtained. ${ }^{1}$ In individuals with low serum magnesium concentration, insulin mediated glucose disposal is decreased. Increase magnesium intake improves glucose and insulin homeostasis. ${ }^{3}$ So it should be considered to supplement magnesium to diabetic patients by physicians as magnesium deficiency contributes to many diabetic complications and exacerbate the disease itself. $^{4}$ Garland $\mathrm{H} \mathrm{O}$ described that, there is potential link between diabetes mellitus is its complications like neuropathy due to magnesium deficiency and also diabetes mellitus is the most frequent chronic disease associated with magnesium deficiency. ${ }^{5}$ Symptoms of peripheral neuropathy are more profound if the patient has low serum magnesium levels. ${ }^{6}$ Engelen W et al. (2000) observed that magnesium supplementation alone could improve nerve conduction under unchanged metabolic control. $^{7}$ 


\section{Materials and Methods}

This study was carried out in the Department of Physiology and Department of Neurology, S.N. Medical College and Associated Hospitals, Agra, over a period of 18 months in diabetic neuropathy patients attending the Neurology O.P.D from February 2009 to august 2010 . The participants $(n=60)$ were divided into 2 groups. Group I consists of 30 diabetic neuropathy patients receiving magnesium supplementation and metformin therapy for a period of 16 weeks. Group II consists of 30 diabetic neuropathy patients of comparable age and sex receiving only metformin therapy.

All patients were subjected to detailed history taking and thorough clinical examination specially focusing on neurological examination, after obtaining his/her informed consent. Patients were required to have at least two of the following:

1. Paresthesia or dysesthesia.

2. Reduced vibratory sense below the knee.

3. Reduced ankle jerk compared to knee jerk.

4. Reduced discrimination and light touch sense distally in the legs.

They were investigated for fasting blood sugar, S. magnesium, blood urea and $\mathrm{S}$. creatinine at first visit $(0$ weeks) and subsequently repeated at 4,8 and 16 weeks.

A nerve conduction study (NCS) is a test commonly used to evaluate the function, especially the ability of electrical conduction, of the motor and sensory nerves of the human body.

Motor NCS is performed by electrical stimulation of a peripheral nerve and recording from a muscle supplied by this nerve.

Note: Decrease in nerve conduction velocity depicts demyelination while decrease in amplitude depicts axonal degeneration

Nerve conduction velocity of lower limb - NCV of Sural Nerve (Sensory) of right side was measured on DOS-based two channel NCV/EMG machine (M/S Recorders \& Medicare System, Chandigarh, India). For

evaluating the level of improvements in the peripheral neuropathy, the type II diabetic neuropathy patients who were attending O.P.D of Neurology clinic, S.N Medical College, Agra were divided into two groups:

Group I: was given magnesium supplementation (Magnesium chloride sustained release tablets) in the doses of $300 \mathrm{mg} / \mathrm{d}$ along with Metformin drug for a period of 16 weeks.

Group II: was given only Metformin for a period of 16 weeks. They were not given any magnesium supplementation. Group II patients were of comparable ages with normal weight for height, on usual diet with no drug taken at the time of examination. Renal and liver function test were normal.

Electrophysiological examination of the tested nerve (Sensory Nerve of right leg) were carried out four times for Group I and Group II patients respectively including the first visit at 0 weeks and the subsequent re-examinations at the end of $4,8,16$ weeks. Average dose of Metformin was $1.5 \mathrm{~g} /$ day.

\section{Inclusion Criteria:}

1. A known case of diabetes mellitus.

2. Patient showing evidences of diabetes mellitus after being investigated for blood sugar.

3. Patients of diabetes mellitus with sign/symptoms suggestive of diabetic polyneuropathy.

\section{Exclusion Criteria:}

1. Patients of diabetes mellitus with altered sensorium or disturbed mental state.

2. Patients of diabetes mellitus, having any other diseases known to cause peripheral neuropathy like chronic renal failure, liver failure, hypothyroidism, leprosy, porphyria etc.

3. Patients with diabetes mellitus taking drugs that are known to cause peripheral neuropathy like Isoniazid, Phenytoin.

4. Patients showing abnormal levels of blood urea, S. Creatinine, Abnormal liver function tests.

\section{Results}

Table 1: Age and sex distribution of diabetic neuropathy patients

\begin{tabular}{|c|c|c|c|c|c|c|c|c|c|c|c|c|}
\hline Age & \multicolumn{4}{|c|}{ Group-I $(n=30)$} & \multicolumn{4}{|c|}{ Group II $(n=30)$} & \multicolumn{4}{|c|}{ Total I \pm II $(\mathrm{n}=60)$} \\
\hline (years) & M & $\mathbf{F}$ & Total & $\%$ & M & $\mathbf{F}$ & Total & $\%$ & $\mathbf{M}$ & $\mathbf{F}$ & Total & $\%$ \\
\hline $41-50$ & 4 & 3 & 7 & 23.3 & 4 & 5 & 9 & 30 & 8 & 8 & 16 & 26.7 \\
\hline $51-60$ & 13 & 7 & 20 & 66.7 & 9 & 5 & 14 & 46.6 & 22 & 12 & 34 & 56.7 \\
\hline $61-70$ & 2 & 1 & 3 & 10.00 & 4 & 2 & 6 & 20 & 6 & 3 & 9 & 15.0 \\
\hline$>70$ & 0 & 0 & 0 & 0 & 1 & 0 & 1 & 3.4 & 1 & 0 & 1 & 1.6 \\
\hline & $\begin{array}{c}19 \\
63.3 \%\end{array}$ & $\begin{array}{c}11 \\
36.7 \%\end{array}$ & 30 & 100 & $\begin{array}{c}18 \\
60 \%\end{array}$ & $\begin{array}{c}12 \\
40 \%\end{array}$ & 30 & 100 & 37 & 23 & 60 & 100 \\
\hline
\end{tabular}

Table 1 depicts the age and sex wise distribution of diabetic neuropathy patients.

In Group I - $66.7 \%$ of neuropathy patients belong to the 51-60 years age group. $23.3 \%$ belong to $41-50$ years age group. No case was found in $>70$ years age group. 4 males and 3 females were in the 41-50 years age group. 13 males and 7 females were in 51-60 years age group. 2 males and 1 female was in 61-70 years age group. Out of 30, 19 males (63.3\%) and 11 females $(36.7 \%)$ were present in group I.

In Group II- $46.6 \%$ belongs to $51-60$ years age group. $30 \%$ belongs to $41-50$ years age group of 
diabetic neuropathy patients. 4 males and 5 females were in 41-50 years age group. 9 males and 5 females were in 51-60 years age group. 4 males and 2 females were in 61-70 years age group. 1 male was present in >
70 age group. Out of 30.18 males $(60 \%)$ and 12 females $(40 \%)$ were present in group II.

In total- out of 60 diabetic patients, 37 were males $(61.7 \%)$ and 23 were females $(38.4 \%)$.

Table 2: sensory nerve conduction velocity of sural nerve $(\mathrm{m} / \mathrm{s})$ before and after treatment

\begin{tabular}{|c|c|c|c|c|c|c|c|c|}
\hline & \multicolumn{4}{|c|}{ Group I $(n=30)$} & \multicolumn{4}{|c|}{ Group II (n=30) } \\
\hline & \multirow{2}{*}{$\begin{array}{c}\text { Before } \\
\text { treatment }\end{array}$} & \multicolumn{3}{|c|}{ After Treatment } & \multirow{2}{*}{$\begin{array}{c}\text { Before } \\
\text { treatment }\end{array}$} & \multicolumn{3}{|c|}{ After Treatment } \\
\hline & & 4 weeks & $\begin{array}{c}8 \\
\text { weeks } \\
\end{array}$ & $\begin{array}{c}16 \\
\text { weeks }\end{array}$ & & $\begin{array}{c}4 \\
\text { weeks }\end{array}$ & $\begin{array}{c}8 \\
\text { weeks } \\
\end{array}$ & $\begin{array}{c}16 \\
\text { weeks }\end{array}$ \\
\hline Mean & 42.23 & 46.85 & 49.57 & 50.62 & 42.89 & 43.74 & 44.13 & 44.53 \\
\hline S.D & 4.16 & 5.47 & 5.94 & 4.65 & 3.43 & 3.45 & 3.32 & 3.40 \\
\hline S.E.M & 0.76 & 0.99 & 1.08 & 0.85 & 0.63 & 0.63 & 0.61 & 0.62 \\
\hline $\begin{array}{l}\text { \% Change } \\
\text { Over Baseline }\end{array}$ & & & & $19.9 \%$ & & & & $3.8 \%$ \\
\hline $\mathrm{p}$ Value & & & & $\mathrm{P}<0.05$ & & & & $\mathrm{p}>0.05$ \\
\hline
\end{tabular}

Table 2 depicts the baseline values (before treatment) of sensory N.C.V $(\mathrm{m} / \mathrm{s})$ of Sural $\mathrm{N}$ before and after treatment values for Group I and Group II at 4, 8 and 16 weeks respectively.

In Group I, mean baseline value for sensory N.C.V of sural nerve is $42.23 \pm 0.76$ and after treatment values at 4 weeks is $46.85+0.99,8$ weeks $49.57 \pm 1.08$ and at 16 weeks $50.62+0.85$ respectively. The difference between before and after treatment was extremely significant in this group.

In Group II, mean baseline value for sensory N.C.V of sural nerve is $42.89 \pm 0.63$ and after treatment values at 4 weeks is $43.74 \pm 0.63,8$ weeks $44.13 \pm 0.61$ and at 16 weeks $44.53 \pm 0.62$ respectively. The difference was observed to be statistically insignificant in this group.

Table 3: Serum magnesium $(\mathrm{mg} / \mathrm{dl})$ before and after treatment

\begin{tabular}{|c|c|c|c|c|c|c|c|c|}
\hline & \multicolumn{4}{|c|}{ Group I $(n=30)$} & \multicolumn{4}{|c|}{ Group II (n=30) } \\
\hline & \multirow{2}{*}{$\begin{array}{c}\text { Before } \\
\text { treatment }\end{array}$} & \multicolumn{3}{|c|}{ After Treatment } & \multirow{2}{*}{$\begin{array}{c}\text { Before } \\
\text { treatment }\end{array}$} & \multicolumn{3}{|c|}{ After Treatment } \\
\hline & & $\begin{array}{c}4 \\
\text { weeks }\end{array}$ & $\begin{array}{c}8 \\
\text { weeks }\end{array}$ & $\begin{array}{c}16 \\
\text { weeks }\end{array}$ & & $\begin{array}{c}4 \\
\text { weeks }\end{array}$ & $\begin{array}{c}8 \\
\text { weeks }\end{array}$ & $\begin{array}{c}16 \\
\text { weeks }\end{array}$ \\
\hline Mean & 1.79 & 1.82 & 1.86 & 1.92 & 1.79 & 1.79 & 1.81 & 1.82 \\
\hline S.D & 0.18 & 0.17 & 0.18 & 0.19 & 0.17 & 0.17 & 0.16 & 0.16 \\
\hline S.E.M & 0.032 & 0.031 & 0.033 & 0.034 & 0.031 & 0.030 & 0.030 & 0.030 \\
\hline $\begin{array}{l}\text { \% Change } \\
\text { Over Baseline }\end{array}$ & & & & $7.3 \%$ & & & & $1.7 \%$ \\
\hline p Value & & & & $\begin{array}{c}\mathrm{p}<0.05 \\
(\mathrm{~S})\end{array}$ & & & & $\begin{array}{c}p>0.05 \\
(N S)\end{array}$ \\
\hline
\end{tabular}

Table 3 depicts the baseline treatment values of $\mathrm{S}$. Magnesium (mg/dl) and after treatment values for Group I and Group II at 4, 8 and 16 weeks respectively.

In Group I, Mean baseline value for S. magnesium is $1.79 \pm 0.032$ and after treatment values at 4 weeks is $1.82 \pm 0.031,8$ weeks $1.86 \pm 0.033$ and at 16 weeks $1.92+0.034$ respectively. In this group we observed that S. magnesium values before and after 16 weeks of magnesium supplementation were highly significant.

In Group II, Mean baseline value for $\mathrm{S}$. Magnesium is $1.79 \pm 0.031$ and after treatment values at 4 weeks is $1.79 \pm 0.030,8$ weeks $1.81+0.030$ and at 16 weeks $1.82 \pm 0.030$ respectively. In this group there was no significant difference in $\mathrm{S}$. magnesium between before and after 16 weeks of treatment

\section{Discussion}

The average age of males was $54.36 \pm 1.18$ years and $55.94 \pm 1.62$ years in group I and II respectively. The average age of females was $53.09 \pm 1.47$ years and $52.83 \pm 1.58$ years in group I and II respectively. In present study mean serum magnesium level in group I, before supplementation i.e at the first visit was $1.79 \pm 0.032 \mathrm{mg} / \mathrm{dl}$. After treatment for 16 weeks, the mean serum magnesium level in Group I was $1.92 \pm 0.034 \mathrm{mg} / \mathrm{dl}$, which is statistically significant $(\mathrm{p}<0.05)$. In group II, the before treatment mean Serum magnesium level was $1.79 \pm 0.031 \mathrm{mg} / \mathrm{dl}$ and after treatment values with no supplementation, after 16 weeks was $1.82+0.030 \mathrm{mg} / \mathrm{dl}$, which was statistically insignificant $(\mathrm{p}>0.05)$. 
In our study the mean value for sensory NCV of sural nerve in group I, before treatment were $42.23 \pm 0.76 \mathrm{~m} / \mathrm{sec}$ and the after treatment values were $50.62 \pm 0.85 \mathrm{~m} / \mathrm{sec}$ after 16 weeks, which were extremely significant $(\mathrm{p}<0.05)$. Group II showed before treatment mean values of sensory NCV of sural nerve as $42.89 \pm 0.63 \mathrm{~m} / \mathrm{sec}$ and after treatment values were $44.53 \pm 0.62 \mathrm{~m} / \mathrm{sec}$ which were statistically insignificant ( $>0.05$ ).

Our results are in accordance with the findings of following studies:

Perkins BA et al. (2001) concluded in their study that Glycemic control is related to the morphological severity of diabetic Sensorimotor Polyneuropathy (DSP) as determined by fiber density (FD) on Sural nerve biopsy. ${ }^{8}$ Ivo De Leeuw et al. (2004) observed that long term Magnesium supplementation influences favourably the natural evolution of neuropathy in $\mathrm{Mg}$ depleted type 1 diabetic patients (T1 DM). Chronic Mg depletion in T1 DM has been linked to Polyneuropathy. ${ }^{9}$ Engelen W et al. (2000) conducted a study which demonstrated that under unchanged metabolic control, supplementation with magnesium could improve nerve conduction. ${ }^{7}$ Elamin $\mathrm{A}$ et al. (1990) observed that appropriate magnesium supplementation might prove beneficial in normalizing the low plasma and tissue Magnesium levels and prevent or retard the development of vascular \& neural complications in diabetic patients. Sophie Begon et al. (2000) observed that magnesium could be an alternative for the treatment of neuropathic pain in patients of diabetic neuropathy. ${ }^{10}$ Phoung -Chi T. Pham et al observed Hypomagnesemia in patients with type 2 diabetes.

\section{Conclusion}

It is thus concluded in our study that magnesium supplementation along with regular anti-diabetic therapy improves sensory nerve conduction velocity and help in the improvement of the symptoms of diabetic neuropathy patients. The limitation of our study was relatively small sample size, so further study involving large number of diabetic neuropathy patients should be done.

Acknowledgement: I would like to thank Dr. C.B Singh, Professor, Department of Physiology S.N.M.C, Agra and Dr. Richa Srivastav, Assistant Professor, Department of Physiology, S.N.M.C, Agra.

\section{Conflict of Interest: None}

Source of Funding: Self-funded study.

Ethical Clearance: Approval of Institutional Ethical Committee was taken to conduct the above study.

\section{References}

1. Ma J, Folsom AR, Melnick SL, Eckfeldt JH, Sharrett AR, Nabulsi AA, Hutchinson RG, Metcalf PA: Associations of serum and dietary magnesium with cardiovascular disease, hypertension, diabetes, insulin, and carotid wall thickness: the ARIC study. J Clin Epidemiol.1985,48:927-940.

2. Amighi J, Sabeti S, Schlager O, Mlekusch W, Exner M, Lalouschek W, Ahmadi R, Minar E, Schillinger M. Low serum magnesium predicts neurological events in patients with advanced atherosclerosis. Stroke. 2004 Jan;35(1):227. Epub 2003 Dec 04.

3. Song Y, Manson J E, Buring J E, Liu S. Dietary Magnesium Intake in Relation to Plasma Insulin Levels and Risk of Type 2 Diabetes in Women Dietary Magnesium Intake in Relation to Plasma Insulin Levels and Risk of Type 2 Diabetes in Women Diabetes Care, 2004 27:59-65.

4. Hasanein P. et al. Oral magnesium administration prevents thermal hyperalgesia induced by diabetes in rats. Department of Biology, Bu-Ali Sina University, Hamadan, Iran. Diabetes Res Clin Pract. 2006;14.

5. Garland HO. New experimental data on the relationship between diabetes mellitus and magnesium. Magnes Res. 1992 Sep;5(3):193-202.

6. Stroud S, Salvato P, Thompson C. Magnesium level and peripheral neuropathy. International Conference on AIDS. Int Conf AIDS. 1994 Aug 7-12;10:202. (abstract no. PB0235). Med. Univ., Charleston, SC.

7. Engelen W, Bouten A, De Leeuw I, De Block C. Are low magnesium levels in type 1 diabetes associated with electromyographical signs of polyneuropathy?. Magnes Res. 2000 Sep;13(3):197-203.

8. Perkins BA, Greene DA, Bril V. Glycemic control is related to the morphological severity of diabetic sensorimotor polyneuropathy. Diabetes Care. 2001 Apr;24(4):748-52.

9. De Leeuw I, Engelen W, De Block C,Van Gaal L. Long term Magnesium supplementation influences favourably the natural evolution of neuropathy in Mg-depleted type 1 diabetic patients (Tldm). Magnes Res. 2004 Jun;17(2):109-14.

10. Begon S, Pickering G, Eschalier A and Dubray C. Effects of Magnesium and MK-801 in two experimental models of neuropathic pain. Brain Res. 2000 Dec 29;887(2):4369.

How to cite this article: Bhardwaj A, Chaurasia P, Chaturvedi A. A study of magnesium supplementation on sensory nerve conduction velocity (N.C.V) in patients of diabetic neuropathy. Ind J Clin Anat Physiol. 2018;5(3):373-376. 